\title{
The Impact of Maternal Pre-Pregnancy Body Weight and Gestational Diabetes on Markers of Folate Metabolism in the Placenta
}

\author{
Jole Martino ${ }^{1,2}$, Maria Teresa Segura ${ }^{2} \oplus$, Luz García-Valdés ${ }^{2}$, M C. Padilla ${ }^{3}$, Ricardo Rueda ${ }^{4}$, \\ Harry J. McArdle ${ }^{5}$, Helen Budge ${ }^{1}$, Michael E. Symonds ${ }^{1,6, *(D)}$ and Cristina Campoy ${ }^{2} \mathbb{C}$ \\ 1 Early Life Research Unit, Division of Child Health and Obstetrics and Gynaecology, \\ Nottingham NG7 2UH, UK; jolemartino78@gmail.com (J.M.); helen.budge@nottingham.ac.uk (H.B.) \\ 2 EURISTIKOS Excellence Centre for Paediatric Research, University of Granada, 18071 Granada, Spain; \\ msegura@ugr.es (M.T.S.); luzgarciavaldes@hotmail.com (L.G.-V.); ccampoy@ugr.es (C.C.) \\ 3 Department of Obstetrics and Gynaecology, University of Granada, 18071 Granada, Spain; \\ carmenpadvin@gmail.com \\ 4 Abbott Nutrition, 18004 Granada, Spain; ricardo.rueda@abbott.com \\ 5 The Rowett Institute of Nutrition and Health, University of Aberdeen, Aberdeen AB24 3FX UK; \\ h.mcardle@abdn.ac.uk \\ 6 Nottingham Digestive Disease Centre, Biomedical Research Unit, School of Medicine, \\ University of Nottingham, Nottingham NG7 2UH, UK \\ * Correspondence: michael.symonds@nottingham.ac.uk; Tel.: +44-11-5823-0625; Fax: +44-11-5823-0627
}

Received: 18 October 2018; Accepted: 10 November 2018; Published: 13 November 2018

\begin{abstract}
Dietary methyl donors, including folate, may modify the placenta and size at birth but the influence of maternal body weight has not been widely investigated. We therefore examined whether maternal or fetal folate status, together with indices of placental folate transport, were modulated by either maternal pre-pregnancy body mass index (BMI i.e., overweight: $25 \leq \mathrm{BMI}<30$ or obesity: $\mathrm{BMI} \geq 30 \mathrm{~kg} / \mathrm{m}^{2}$ ) and / or gestational diabetes mellitus (GD). We utilised a sub-sample of 135 pregnant women participating in the Spanish PREOBE survey for our analysis (i.e., 59 healthy normal weight, 29 overweight, 22 obese and 25 GD). They were blood sampled at 34 weeks gestation, and, at delivery, when a placental sample was taken together with maternal and cord blood. Placental gene expression of folate transporters and DNA methyltransferases (DNMT) were all measured. Folate plasma concentrations were determined with an electro-chemiluminescence immunoassay. Food diaries indicated that folate intake was unaffected by BMI or GD and, although all women maintained normal folate concentrations (i.e., $5-16 \mathrm{ng} / \mathrm{mL}$ ), higher BMIs were associated with reduced maternal folate concentrations at delivery. Umbilical cord folate was not different, reflecting an increased concentration gradient between the mother and her fetus. Placental mRNA abundance for the folate receptor alpha (FOLR1) was reduced with obesity, whilst DNMT1 was increased with raised BMI, responses that were unaffected by GD. Multi-regression analysis to determine the best predictors for placental FOLR1 indicated that pre-gestational BMI had the greatest influence. In conclusion, the placenta's capacity to maintain fetal folate supply was not compromised by either obesity or GD.
\end{abstract}

Keywords: body mass index; gestational diabetes; placenta; folic acid

\section{Introduction}

Folate is an essential cofactor in metabolic pathways that influence DNA methylation patterns, DNA synthesis and cell proliferation [1,2]. It is crucial to the 1-carbon cycle where it acts as a transporter of $\mathrm{CH} 3$ and the single carbon donor in one carbon metabolism [3]. Limited dietary availability can 
contribute to abnormal DNA methylation patterns in mice [4] and, thus, potentially to developmental programming [5]. Fortification of the diet with folic acid has been adopted by many countries to ensure that dietary intake is rarely limited, particularly during pregnancy, in order to prevent neural tube defects when folate requirements can increase because of increased rates of cell division and growth, especially during embryo development [6,7]. Indeed, it is now recommended that, during pregnancy, there should be no upper limit on dietary intake [8]. Pregnant women with high body mass index (BMI) and gestational diabetes (GD) can have inadequate dietary intakes of folate [9-11] and lower folate concentrations $[12,13]$. This could contribute to some of the adverse neonatal outcomes associated with maternal obesity [14], including greater risks of preterm deliveries, neural tube defects and low birth weight [15-17].

Cellular uptake of folate is mediated by specific transport mechanisms in the placenta, which include the folate receptor alpha (FOLR1), proton coupled folate transporter (PCFT), and folate carrier (RFC) [18,19]. Of these mechanisms, FOLR1 appears to be the most important, at least as far as preterm births are concerned [20]. Folate is bound to the FOLR1 on the maternal side of the placenta and then transported to the fetal circulation by endocytosis/exocytosis [21]. The impact of maternal obesity on the potential capacity of the placenta to modulate folate status acting through FOLR1 has not been examined extensively in humans. One study in women in Texas found that when gestational weight gain was similar in obese and non-obese women, fetal serum folate concentrations and placental folate transport activity were unaffected [22].

The present study, was designed to explore the effects of a raised maternal pre-pregnancy $\mathrm{BMI}$ and/or gestational diabetes on markers of folate placental transport and metabolism, taking into account folic acid status and intake under these different maternal metabolic environments. We hypothesised that as folate has a crucial role in providing methyl donors [3], it can influence gene expression for DNA methyltransferases (DNMT1) and DNMT3A [4]. We therefore examined whether potential changes in placental folate transport resulting from high maternal BMI and/or GD, would modulate gene expression of DNMT. Our study was conducted in pregnant women from Spain recruited as part of the PREOBE study in which we have previously shown that placental expression of genes involved in energy sensing and oxidative stress are sensitive to maternal obesity (i.e., $\mathrm{BMI} \geq 30 \mathrm{~kg} / \mathrm{m}^{2}$ ) and GD [23].

\section{Materials and Methods}

\subsection{Participants}

The participants were part of a longitudinal study on the influence of body composition by maternal genetics and nutrition (PREOBE Excellence Project: P06-CTS-02341) undertaken between 2007 and 2010 and registered with www.ClinicalTrials.gov, (NCT01634464) [24-26] for which full details have already been published (and are summarised in Table 1 [23]). It was conducted according to the guidelines in the Declaration of Helsinki and all experimental procedures were approved by the Ethics Committees for Granada University, San Cecilio University Hospital and the University of Nottingham. Witnessed, written informed consent was obtained from all participants before their study inclusion and they were assured of anonymity. Anthropometric assessments of mothers and newborns were undertaken following the standards established by the Spanish Society of Gynaecology and Obstetrics, the Fetal Foundation and the Spanish Association of Paediatrics. Gestational Diabetes was diagnosed according to the Spanish consensus protocol established by the Grupo Español de Diabetes y Embarazo (GEDE) of the Gynecology and Obstetricians Society, followed by Andalusian pregnant women general practitioners [27]. The O'Sullivan test was performed on all pregnant women between 24-28 weeks of pregnancy, as screening for gestational diabetes. If glucose was $\geq 140 \mathrm{mg} / \mathrm{dL}$ an oral glucose tolerance test (OGTT) with $100 \mathrm{~g}$ of glucose loading was performed. Gestational diabetes was diagnosed if two or more glucose values met or exceeded the following values fasting $<105 \mathrm{mg} / \mathrm{dL}$, one hour <190 mg/dL, two hours <165 mg/dL, three hours <145 mg/dL. Women with 
plasma glucose $\geq 200 \mathrm{mg} / \mathrm{dL}$ after O'Sullivan test were diagnosed of gestational diabetes and OGTT was not performed. The O'Sullivan screening test was also performed in the first trimester in high risk pregnant women (maternal age $>35$ years; $\mathrm{BMI}>30 \mathrm{~kg} / \mathrm{m}^{2}$, previous gestational diabetes or other glucose metabolic alterations, previous obstetric results with an indication of undiagnosed gestational diabetes (e.g., foetal macrosomy), family history of diabetes mellitus, ethnic risk groups (Afroamericans, Asiatic-Americans, Hispanic, Indio-Americans))

Table 1. Summary of maternal age, body and birth weights of all participants.

\begin{tabular}{|c|c|c|c|c|c|}
\hline & $\mathrm{N}(n=59)$ & OW $(n=29)$ & $\mathrm{O}(n=22)$ & GDN $(n=14)$ & GDO $(n=11)$ \\
\hline \multicolumn{6}{|l|}{ Maternal characteristics } \\
\hline Age at delivery (years) & $30.4 \pm 4.5$ & $30.9 \pm 7.2$ & $29.0 \pm 4.7$ & $33.1 \pm 4.1 *$ & $34.7 \pm 4.3^{* *}$ \\
\hline Height $(\mathrm{cm})$ & $162.9 \pm 5.7$ & $162.5 \pm 6.4$ & $162.7 \pm 6.2$ & $159.3 \pm 3.9$ & $160.5 \pm 6.0$ \\
\hline Pre pregnancy BMI $\left(\mathrm{kg} / \mathrm{m}^{2}\right)$ & $21.8 \pm 1.8$ & $27.8 \pm 2.2^{* * *}$ & $32.5 \pm 2.6^{* * *}$ & $22.4 \pm 1.8$ & $35.5 \pm 4.9^{* * *}$ \\
\hline BMI at 34 weeks $\left(\mathrm{kg} / \mathrm{m}^{2}\right)$ & $26.6 \pm 2.6$ & $31.3 \pm 2.4^{* * *}$ & $35.4 \pm 2.4^{* * *}$ & $25.9 \pm 2.6$ & $36.4 \pm 4.1^{* * *}$ \\
\hline GWG 0-34 weeks (kg) & $12.6 \pm 4.3$ & $9.9 \pm 4.6^{* *}$ & $7.3 \pm 5.1^{* * *}$ & $9.0 \pm 5.6^{* *}$ & $2.2 \pm 7.8^{* * *}$ \\
\hline Preterm (<37 gestational weeks) $(n)$ & $2(3 \%)$ & $1(3 \%)$ & $2(9 \%)$ & $1(14 \%)$ & $4(27 \%) *$ \\
\hline Male newborn $(\%)$ & 53 & 40 & 62 & 57 & 73 \\
\hline Number of caesarean section (\%) & 12 & 26 & 38 & 25 & 50 \\
\hline Number on supplements ${ }^{+}$ & 45 & 26 & 22 & 12 & 9 \\
\hline \multicolumn{6}{|l|}{ Infant characteristics } \\
\hline Newborn weight (g) & $3292 \pm 410$ & $3230 \pm 587$ & $3454 \pm 549$ & $3374 \pm 402$ & $3415 \pm 549$ \\
\hline Placental weight $(\mathrm{g})$ & $469 \pm 120$ & $495 \pm 135$ & $531 \pm 114 *$ & $498 \pm 134$ & $476 \pm 93$ \\
\hline Placental: birth weight ratio & $0.14 \pm 0.03$ & $0.16 \pm 0.05$ & $0.16 \pm 0.04$ & $0.15 \pm 0.04$ & $0.14 \pm 0.02$ \\
\hline Gestational age (weeks) & $39.2 \pm 1.0$ & $39.4 \pm 1.6$ & $39.3 \pm 1.7$ & $39.3 \pm 1.3$ & $38.8 \pm 1.3$ \\
\hline
\end{tabular}

Pre: pregestational; BMI: body mass index; GWG: gestational weight gain during the first 34 gestational weeks based on 2009 IOM guidelines for each category [28]. ${ }^{+}$reported taking folate and iodine supplements at 24th week of gestation. Values are means $\pm \mathrm{SD}$ or categorical data as appropriate; $\mathrm{n}$ : number of women per group; gw: weeks of gestational. Statistical differences: ${ }^{*} p<0.05,{ }^{* *} p<0.01,{ }^{* * *} p<0.001$ compared to normal w eight group (Chi-square test or t-independent test for continuous variables; chi-square test for categorical variables). Based on their prepregnancy weights they were classified as being of normal weight $(\mathrm{N})$, overweight $(\mathrm{OW})$, obese $(\mathrm{O})$, gestational diabetic, normal weight (GDN) or gestational diabetic, obese (GDO) pregnant women (Martino et al., 2016) [23].

As shown in Table 1, the subpopulation of 135 participants whose placentas underwent molecular analysis in Nottingham, for which a majority that gave birth at full term i.e., c. 39 weeks [23], with the exception of GDO for which 50\% underwent caesarean section delivery. The number of participants per group were, therefore, 59 normal weight women (18 $\leq$ pre-pregnancy BMI $<25 \mathrm{~kg} / \mathrm{m}^{2}$ $(\mathrm{N})), 29$ overweight women $\left(25 \leq \mathrm{BMI}<30 \mathrm{~kg} / \mathrm{m}^{2}(\mathrm{OW})\right)$ and 22 obese women (BMI $\geq 30 \mathrm{~kg} / \mathrm{m}^{2}$ (O)). Furthermore, the 25 mothers with GD were subsequently classified according to their BMI as normal weight GD (pre-pregnancy BMI $<25 \mathrm{~kg} / \mathrm{m}^{2}(\mathrm{GDN}), n=14$ ) and as obese GD (pre-pregnancy $\left.\mathrm{BMI} \geq 30 \mathrm{~kg} / \mathrm{m}^{2}(\mathrm{GDO}), n=11\right)$. There were no effects of the sex of the baby, route of delivery or gestational age on any of the measurements reported in this study.

\subsection{Maternal Nutrient Intake}

Information about maternal nutrient intake was collected during late gestation (34-40 weeks) using standardised 7 day dietary records given to the participants during the second visit (34th gestational week). Each participant was given verbal and written instructions by the investigator on how to record food and drinks consumed during the 7 day recording period and a booklet of common food items and mixed dishes to facilitate estimation of portion sizes. Around the time of delivery, food records were reviewed with each mother by a nutritionist for completeness and accuracy of food description and portion sizes. Nutritional data were analysed for nutrient intake by using a nutritional software program (CESNID 1.0: Barcelona University, Spain) based on validated Spanish food tables ("Tablas de composición de alimentos del CESNID") [29] and took account of those products fortified with folic acid. 


\subsection{Collection and Analysis of Blood Samples}

Maternal venous blood was collected at 34 weeks of gestation and during labour (N: $n=59$; OW: $n=29$; O: $n=22$; GDN: $n=14$; GDO: $n=11)$. Umbilical venous blood samples (N: $n=33$; OW: $n=15$; O: $n=12$; GDN: $n=7$; GDO: $n=7$ ) were collected within 30 min after placental delivery from a double-clamped section of umbilical cord. EDTA and serum collection tubes were used (Vacutainer ${ }^{\circledR}$ Refs: 368857 and 367953) for haematological assessment and biochemical analyses respectively. There were no differences in any of the measurements performed on the placenta between those women from whom blood was sampled and those in whom this could not be achieved e.g., born at a time when sampling could not be undertaken.

Blood samples for serum preparation were held at $4{ }^{\circ} \mathrm{C}$ for $15 \mathrm{~min}$ to allow blood clotting, centrifuged at $3500 \mathrm{rpm}$ for $10 \mathrm{~min}$ at $4{ }^{\circ} \mathrm{C}$, and the serum fraction transferred into sterile tubes. Samples were stored at $4{ }^{\circ} \mathrm{C}$ for same-day analyses or at $-80{ }^{\circ} \mathrm{C}$ for further analysis. Serum folate was determined by an electro-chemiluminescence immunoassay with the automatic analyser Elecsys 2010, and the analytical kit No. E170 (Roche, Neuilly sur Seine, France).

\subsection{Collection of Placenta Samples}

Placenta samples from all participants were collected and weighed immediately after delivery as previously published [23]. Visual inspection of the placenta for necrosis or any other abnormality was undertaken by experienced clinicians. A representative $0.5 \times 0.5 \times 0.5 \mathrm{~cm}(200 \mathrm{mg})$ sample was excised from the middle of the radius (distance between the insertion of the umbilical cord and the periphery) of each placenta, rinsed twice with saline solution $(0.9 \% \mathrm{NaCl})$ and immediately placed into sterile $1.5 \mathrm{~mL}$ microtubes (Greiner Bio One, Monroe, NC, USA) containing RNAlater solution (Qiagen Ltd., Crawley, UK). All samples were frozen under RNase free conditions using liquid nitrogen before storage at $-80^{\circ} \mathrm{C}$ for later analysis in Nottingham.

\subsection{Laboratory Analysis}

Total RNA was extracted from $100 \mathrm{mg}$ of maternal placenta tissue using $200 \mu \mathrm{L}$ of chloroform per $1 \mathrm{~mL}$ of TRI reagent solution (Sigma Chemical Co., Poole, UK) and RNeasy extraction kit (Qiagen Ltd., Crawley, UK) as previously published [23]. RNA quality was assessed by gel electropheresis. Two $\mu \mathrm{g}$ RNA was used to generate $20 \mu \mathrm{L}$ cDNA using High Capacity RNA-to-cDNA kit (Applied Biosystems, Foster City, CA, USA). Negative control RT samples lacking Enzyme Mix (-RT) were included for each sample. Real-time PCR using $15 \mu \mathrm{L}$ of reactions consisting of $4.5 \mu \mathrm{L}$ diluted 1:10 cDNA, 3.0 $\mu \mathrm{L}$ (final concentration of $250 \mathrm{nM}$ ) gene specific primers (Table 2, Sigma-Aldrich, St. Louis, MO, USA), and 7.5 $\mu \mathrm{L}$ of SYBR Green mastermix (Thermo Scientific, ABgene Ltd., Epson, UK) were performed. Duplicate samples were run for 40 cycles with negative controls in 96-well plates using the Techne Quantica Thermocycler (Techne Inc., Barloword Scientific, Stone, UK). Ten-fold serial dilutions of cDNA for each gene were used to generate standard curve analysis and only experiments with $R^{2}$ $>0.985$ were included. CT measurements, calculated by $2^{-\Delta C t}$ method [30], were used for mRNA expression. A range of housekeeping genes were used including ACT8, 18S and B2M, for which $18 \mathrm{~S}$ ribosomal RNA was used as the optimal housekeeping gene for data normalisation, as previously published [23]. It was the most stable housekeeping examined (i.e., N: $0.37 \pm 0.08$; OW $0.70 \pm 0.28$; OB $0.56 \pm 0.11$; GDL: $0.75 \pm 0.14$; GDO: $0.13 \pm 0.02$ a.u.) and the use of other reference genes made no difference to the results. 
Table 2. Summary of primers used together with $\mathrm{qPCR}$ product and conditions.

\begin{tabular}{lllcc}
\hline Target Gene & Forward Primer Sequence & Reverse Primer Sequence & Product Size (bp) & Temp $\left({ }^{\circ} \mathbf{C}\right)$ \\
\hline FOLR 1 & CACTCCCTGCCTGTCTCC & TCTGCTCTGCTCTACACTCC & 80 & 59 \\
PCFT $(S L C 46 A 1)$ & ATGCAGCTTTCTGCTTTGGT & GGAGCCACATAGAGCTGGAC & 100 & 60 \\
RFC $(S L C 19 A 1)$ & CAGCATCTGGCTGTGCTATG & TGATGGTCTTGACGATGGTG & 161 & 116 \\
MTHFR & TCCCGTCAGCTTCATGTTCT & TGTCGTGGATGTACTGGATGA & 59 \\
DNMT1 & TTCTTCGCAGAGCAAATTGA & CGTCATCTGCCTCCTTCATGG & 210 & 59 \\
DNMT3A & AAGCCTCAAGAGCAGTGGAA & AAGCAGACCTTTAGCCACGA & 190 & 59 \\
\hline
\end{tabular}

FOLR1: folate receptor alpha; PCFT: proton coupled folate transporter; RFC: reduced folate carrier; MTHFR: methylenetetrahydrofolate reductase; DNMT1: DNA methyl transferase-1; DNMT3A: DNA methyl transferase-3 alpha. bp, base pairs.

\subsection{Statistical Analysis}

All statistical evaluations were performed by using IBM SPSS v20.0 statistical software for Windows (IBM Corp., Armonk, NY, USA). To assess the data for normality, a Kolmogorov-Smirnov test was performed, where $p$ values $>0.05$ indicated that the data were normally distributed. Thereafter, appropriate parametric, or non-parametric, tests were used to analyse the effects of maternal overweight and obesity as follows: (1) comparisons of blood folate concentration at each sampling age between comparable groups (i.e., $\mathrm{N}$ vs. OW, or $\mathrm{O}$, or GDN; GDN vs. GDO) were made by independent $t$-test; whilst (2) differences in gene expression were determined by using Mann-Whitney test. Categorical data were analysed using Chi-square test of independence. Continuous data (i.e., gene expression and folate concentrations) presented are expressed as means with their standard errors (SEM), with $p$ values $<0.05$ deemed to represent statistical significance. For all analyses undertaken, there was no effect of foetal sex or route of delivery.

Association between continuous variables were also assessed using multiple linear regression analysis. It included the following three models: The first was adjusted for the a priori confounder of pre-gestational BMI; the second, for both BMI and maternal glucose at 34 weeks of gestation and the third for BMI, maternal glucose and folate at 34 weeks gestation.

\section{Results}

Maternal Folate Status and Adaptations within the Placenta

Amongst those participants for whom placental analysis was undertaken and who reported daily intakes of folate ( $400 \mu \mathrm{g}$ dietary folate equivalents/day) and iodine supplements at 24th week of pregnancy, there were no differences in folate or vitamin B12 consumption between groups (Table 3). Folate concentrations in all participants in the present study were within the normal range (6-20 ng/mL) with no evidence of folate deficiency (defined as $<5 \mathrm{ng} / \mathrm{mL}$ : Figure 1) [7]. GDN women exhibited the highest serum folate concentrations at 34 gestational weeks compared to the normal weight group (Figure 1). This could reflect dietary and related advice given to this sub-group, in which mean folate and vitamin B12 intakes were also highest (Table 3). There was no significant effect of taking folate supplements in late gestation on maternal folate concentrations at 40 weeks of gestation. A marked decrease in folate concentrations in late pregnancy was observed in both $\mathrm{OW}$ and $\mathrm{O}$ women (Figure 1). Cord blood folate concentrations were not different between groups, reflecting an increased difference between maternal folate at 40 gestational weeks and umbilical cord folate with raised maternal BMI (i.e., $\Delta$ folate-N: $5.80 \pm 0.81$; OW: $7.66 \pm 0.82 ;$ O: $9.01 \pm 0.90 \mathrm{ng} / \mathrm{mL}$ $(p<0.05))$. There was also a positive correlation between maternal and newborn plasma folate in the $\mathrm{N}\left(r^{2}=0.38 ; p<0.0001\right)$ and GDN $\left(r^{2}=0.81 ; p=0.015\right)$ groups at 34 weeks gestation and in the $\mathrm{N}$ $\left(r^{2}=0.19 ; p=0.013\right)$ and OW $\left(r^{2}=0.48 ; p=0.006\right)$ groups at 40 weeks gestation. No infants exhibited any spinal or neural abnormalities. 
Table 3. Mean maternal 7 day dietary intake of folate and vitamin B12 between 34-40 weeks gestation for each group of women whose body weight category was defined according to their pre pregnancy BMI.

\begin{tabular}{lccccc}
\hline $\begin{array}{l}\text { Maternal Intake } \\
(\boldsymbol{\mu g} \text { DFE/day })\end{array}$ & $\begin{array}{c}\mathbf{N} \\
(\boldsymbol{n}=\mathbf{3 7 )}\end{array}$ & $\begin{array}{c}\text { OW } \\
(\boldsymbol{n}=\mathbf{1 5})\end{array}$ & $\begin{array}{c}\text { O } \\
(\boldsymbol{n}=\mathbf{8})\end{array}$ & $\begin{array}{c}\text { GDN } \\
(\boldsymbol{n}=\mathbf{1 1})\end{array}$ & $\begin{array}{c}\text { GDO } \\
(\boldsymbol{n}=\mathbf{6})\end{array}$ \\
\hline Folate & $298 \pm 12$ & $258 \pm 18$ & $260 \pm 46$ & $342 \pm 33$ & $299 \pm 53$ \\
Vitamin B12 & $5.8 \pm 0.5$ & $4.7 \pm 0.5$ & $5.3 \pm 0.9$ & $10.1 \pm 4.1$ & $5.3 \pm 1.2$ \\
\hline
\end{tabular}

DEF, dietary folate equivalents. Normal weight: $\mathrm{N}$; overweight: $\mathrm{OW}$; obese: $\mathrm{O}$, gestational diabetic, normal weight: GDN and gestational diabetic, obese: GDO. Values are means \pm SD.

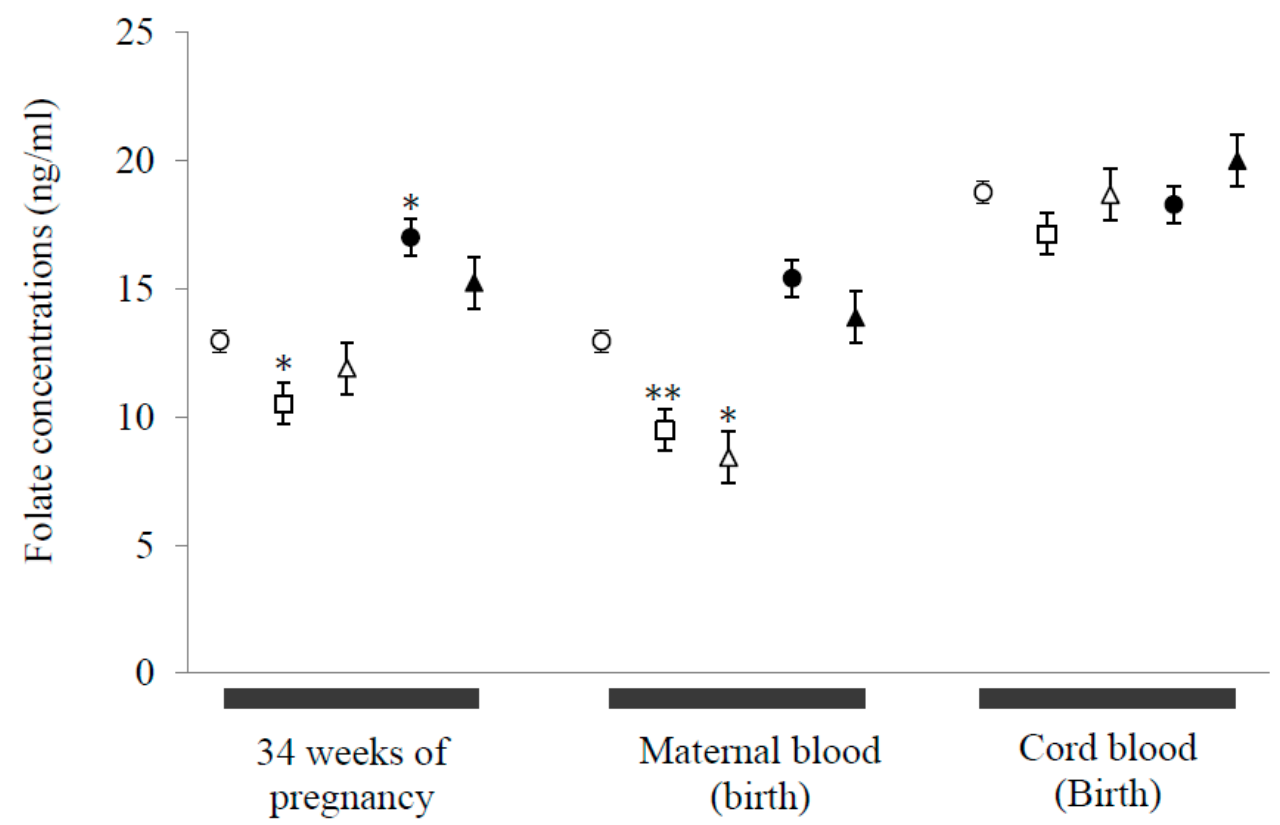

Figure 1. Effects of maternal pre-pregnancy BMI and gestational diabetes on maternal and neonatal folate serum concentrations. Maternal samples were taken at 34 weeks gestation and at term/delivery i.e., c. 39 weeks of pregnancy, neonatal samples were taken from cord blood at birth. Open circles: normal weight ( $\mathrm{N}$ : maternal, $n=59$; cord, $n=33$ ); open squares: overweight (OW: maternal, $n=29$; cord, $n=15$ ); open triangles: obese (O: maternal, $n=22$; cord, $n=12)$; closed circles: gestational diabetic, normal weight (GDN: maternal, $n=14$; cord, $n=7)$; closed triangles: gestational diabetic, obese women (GDO: maternal, $n=11$; cord, $n=7$ ). Values represent means \pm S.E.M. Statistical differences between groups denoted at each time point by ${ }^{*},{ }^{* *}$ correspond to $p<0.05, p<0.01$ respectively compared to normal weight control group (independent $t$ test for continuous variables).

Placentas from obese women showed a significantly lower expression of FOLR1, a response that was unaffected by GD (Table 4). Multi-regression analysis of predictors for placental FOLR1 gene expression, indicated that pre-pregnancy BMI had the greatest influence (Table 5), suggesting an effect present in early gestation. Gene expression of placental methylenetetrahydrofolate reductase $(\mathrm{NAD}(\mathrm{P}) \mathrm{H})(\mathrm{MTHFR})$, the enzyme that catalyses the synthesis of 5-MTHF, did not significantly change between BMI groups, but was raised in obese women with GD (Table 4). Whilst placental DNMT3A gene expression was similar between groups, mean mRNA expression of DNMT1 was higher in overweight and women (Table 4). No significant correlations were found between placental gene expression and plasma folate. 
Table 4. Effects of maternal body mass index on gene expression markers of folate transport and metabolism and DNA methylation in placenta of normal weight $(\mathrm{N})$, overweight $(\mathrm{OW})$, obese $(\mathrm{O})$, gestational diabetic, normal weight (GDN) and gestational diabetic, obese (GDO) pregnant women.

\begin{tabular}{|c|c|c|c|c|c|c|c|}
\hline Pathway & $\begin{array}{c}\text { NCBI } \\
\text { Sequence }\end{array}$ & $\begin{array}{l}\text { Target } \\
\text { Gene }\end{array}$ & $\begin{array}{c}\mathrm{N} \\
(n=59)\end{array}$ & $\begin{array}{c}\text { OW } \\
(n=29)\end{array}$ & $\begin{array}{c}\mathrm{O} \\
(n=21)\end{array}$ & $\begin{array}{c}\text { GDN } \\
(n=14)\end{array}$ & $\begin{array}{c}\text { GDO } \\
(n=11)\end{array}$ \\
\hline \multirow{4}{*}{$\begin{array}{l}\text { Folate transport } \\
\text { and metabolism }\end{array}$} & NM_016725.2 & FOLR1 & $1.0 \pm 0.9$ & $0.8 \pm 0.6$ & $0.5 \pm 0.3 *$ & $0.6 \pm 0.3$ & $0.5 \pm 0.3 *$ \\
\hline & NM_080669.4 & PCFT $\Psi$ & $1.0 \pm 0.6$ & $1.0 \pm 0.5$ & $1.1 \pm 0.6$ & $0.6 \pm 0.7$ & $0.8 \pm 0.5$ \\
\hline & NM_006996.2 & $R F C^{\psi}$ & $1.0 \pm 0.8$ & $0.9 \pm 0.5$ & $1.0 \pm 0.7$ & $0.8 \pm 0.5$ & $0.7 \pm 0.5$ \\
\hline & NM_005957 & MTHFR & $1.0 \pm 0.9$ & $1.0 \pm 0.9$ & $0.8 \pm 0.6$ & $1.0 \pm 0.7$ & $1.5 \pm 0.7^{*}$ \\
\hline DNA & NM_001130823 & DNMT1 & $1.0 \pm 1.1$ & $1.8 \pm 1.1^{* *}$ & $1.5 \pm 1.2$ & $1.8 \pm 1.5$ & $0.5 \pm 0.5$ \\
\hline methylation & NM_022552.4 & DNMT3A & $1.0 \pm 0.9$ & $1.1 \pm 1.2$ & $0.7 \pm 0.5$ & $0.9 \pm 0.9$ & $0.6 \pm 0.3$ \\
\hline
\end{tabular}

Data expressed relative to housekeeping gene (ribosomal 18S RNA), normalised to the control group to give the fold change. $n=$ women/group. Data are non-parametric and represent mean \pm SD Statistical differences: $* p<0.05,{ }^{* *} p<0.01$ compared to normal weight group (Mann Whitney test). The abundance of genes denoted by $\psi$ were measured in a representative selection of $20 \mathrm{~N}$ women as insufficient mRNA was not available for all samples. FOLR1: folate receptor alpha; PCFT: proton coupled folate transporter; RFC: reduced folate carrier; MTHFR: methylenetetrahydrofolate reductase; DNMT1: DNA methyl transferase-1; DNMT3A: DNA methyl transferase-3 alpha.

Table 5. Association between placental gene expression of folate receptor alpha (FOLR1) and different predictors in control, overweight and obese pregnant women with or without gestational diabetes $(n=135)$.

\begin{tabular}{lcccc}
\hline $\begin{array}{l}\text { Linear Regression } \\
\text { Model }\end{array}$ & $\boldsymbol{B}(\mathbf{9 5 \%} \mathbf{C I})$ & SE B & $\boldsymbol{\beta}$ & $\boldsymbol{p}$ \\
\hline $\begin{array}{l}\text { Model 1 } \psi \\
\text { Maternal pre-BMI }\end{array}$ & $-0.029(-0.051,-0.007)$ & 0.011 & -0.214 & 0.009 \\
\hline Model 2 $\psi$ & & & & \\
Maternal pre-BMI & $-0.032(-0.054,-0.009)$ & 0.011 & -0.230 & 0.006 \\
Maternal glucose (34 gw) & $0.004(-0.002,0.01)$ & 0.003 & 0.107 & 0.194 \\
\hline Model 3 $\psi \psi$ & & & & \\
Maternal pre-BMI & $-0.033(-0.056,-0.011)$ & 0.012 & -0.241 & 0.004 \\
Maternal glucose (34 gw) & $0.005(-0.001,0.01)$ & 0.003 & 0.131 & 0.116 \\
Maternal folate (34 gw) & $-0.019(-0.043,0.005)$ & 0.012 & 0.128 & 0.124 \\
\hline
\end{tabular}

$\psi$ Adjusted for the a priori confounders pre-pregnancy BMI; $\psi \psi$ adjusted for the a priori confounders pre-pregnancy BMI and maternal glucose at 34 weeks of gestation $(\mathrm{gw}) ; \psi \psi \psi$ Adjusted for the a priori confounders pre-pregnancy BMI, maternal glucose at $34 \mathrm{gw}$ and maternal folate at $34 \mathrm{gw}$. B: unstandardised beta; $95 \%$ CI: 95\% Confidence intervals; SE B: Standard error of unstandardised beta; $\beta$ : standardised beta $(\beta)$.

\section{Discussion}

We show that although maternal folate concentrations were reduced with raised maternal pre-pregnancy BMI near to term, this was not apparent with GD, suggesting that the dietary advice provided improved folate status irrespective of any placental adaptations, as seen with obesity. In those women with raised pre-pregnancy BMI, there was no detectable reduction in cord blood folate and all infants were healthy at term. This suggests appropriate adaptation in folate transfer across the placenta, that has been suggested to include a downregulation of FOLR1 gene expression in the placenta with obesity [19]. The results from our study support such a proposal as gene expression for the other two transporters, PCFT and RFC, were unaffected. Raised mRNA abundance of FOLR1, if translated to protein, and accompanied with a decline in maternal folate concentration would result in the maintenance of cord blood folate as we observed at term with obesity. Alternatively mRNA transcripts of this folate transporter could undergo further functional modifications, that modulate the placentas capacity to promote folate transport [31] and, hence, protect normal foetal folate status as seen in women from Texas, USA [22].

The negative association between raised pre-pregnancy BMI and folate status did not appear to be related to dietary inadequacy in these women unlike those described by others [9-11]. It is possible that 
other adaptations to a high pre-pregnancy BMI, such as hormonal changes in pregnancy and endocrine modifications, could contribute [6]. It is possible that adaptations within the maternal microbiome could impact on maternal folate status [32], as has been shown in the rat during late gestation when manipulating macronutrient intake [33]. Interestingly, obesity with GD resulted in raised placental MTHFR gene expression that could ultimately inhibit intracellular homocysteine release by promoting 5-MTHF synthesis [34-36]. Enhanced folate catabolism by the placenta would also limit homocysteine accumulation within the trophoblast, thereby avoiding foetal complications in women with obesity and/or GD [35,37].

As folate deficiency has been associated with increased placental S-adenosyl-methionine to S-adenosyl-homocysteine ratio [38,39] and decreased genomic DNA methylation [40-43], reduced blood folate with obesity could lower the availability of placental SAM, which is used by DNMTs to methylate DNA $[2,44,45]$. Changes in gene expression for DNMT1 could be important in this regard as it transcribes the enzyme required for the maintenance of DNA methylation [46] although this was not measured in the present study. DNMT1 is also essential for cellular development [46] and our observation of raised placental gene expression with increased BMI could impact on these processes even though DNMT3A was unaffected. These divergent responses could reflect their contrasting roles, with DNMT3A catalysing de novo DNA methylation during early development, whilst DNMT1 is responsible for the maintenance of DNA methylation throughout all development stages [4]. The decreased maternal folate with raised pre-pregnancy BMI and higher mRNA abundance of DNMT1 in the placenta with similar cord blood folate concentrations, could be indicative of a compensatory response in order to maintain adequate methylation status, for which no differences were found when measured in five subjects per study group [47]. Overall the relatively small sample size was utilised in our study, which might benefit from being undertaken in larger groups of women of different ethnicity. Such a broader study could be combined with a more detailed assessment of those epigenetic adaptations which remain to be clarified [48].

\section{Conclusions}

In conclusion, pregnancies in Spanish women with a high BMI and GD are differentially associated with changes in maternal serum folate in late gestation, which suggests a protective role by the placenta of the foetus, further supporting the need to ensure optimal dietary folate intake [8].

Author Contributions: J.M.- conducted placental analysis, performed all statistical analysis and co-drafted manuscript. M.T.S.- collected samples and patient information. L.G.-V.-collected patient information and conducted blood sample analysis. M.C.P.—collected samples and patient information. R.R.-co-formulated the research question, co-supervised the project and edited the manuscript. H.J.M.-co-supervised the project and edited the manuscript. H.B.-co-supervised the project and edited the manuscript. M.E.S.-co-supervised the project and co-drafted the manuscript. C.C.- co-formulated the research question, led the project and edited the manuscript.

Funding: The Spanish Ministry of Innovation and Science, Junta de Andalucía (Ref. N ${ }^{\circ}$ : P06-CTS-0234), Spanish Ministry of Economy and Competitiveness (Grant no. BFU2012-40254-C03-01); Abbott Nutrition, Spain; The Nottingham Respiratory Biomedical Research Unit, and the Nottingham University Hospitals Charity. This work was also supported by the Medical Research Council (Grant numbers G0800129-1 and 1G0600310).

Acknowledgments: The authors wish to thank participants and clinical staff for their support of this study.

Conflicts of Interest: The authors declare no conflicts of interest.

\section{References}

1. Portela, A.; Esteller, M. Epigenetic modifications and human disease. Nat. Biotechnol. 2010, 28, $1057-1068$. [CrossRef] [PubMed]

2. Filiberto, A.C.; Maccani, M.A.; Koestler, D.C.; Wilhelm-Benartzi, C.; Avissar-Whiting, M.; Banister, C.E.; Gagne, L.A.; Marsit, C.J. Birthweight is associated with DNA promoter methylation of the glucocorticoid receptor in human placenta. Epigenetics 2011, 6, 566-572. [CrossRef] [PubMed] 
3. Kim, J.M.; Hong, K.; Lee, J.H.; Lee, S.; Chang, N. Effect of folate deficiency on placental DNA methylation in hyperhomocysteinemic rats. J. Nutr. Biochem. 2009, 20, 172-176. [CrossRef] [PubMed]

4. $\quad$ Ding, Y.B.; He, J.L.; Liu, X.Q.; Chen, X.M.; Long, C.L.; Wang, Y.X. Expression of DNA methyltransferases in the mouse uterus during early pregnancy and susceptibility to dietary folate deficiency. Reproduction 2012, 144, 91-100. [CrossRef] [PubMed]

5. Barres, R.; Zierath, J.R. DNA methylation in metabolic disorders. Am. J. Clin. Nutr. 2011, 93, 897S-900S. [CrossRef] [PubMed]

6. Kim, H.; Hwang, J.Y.; Kim, K.N.; Ha, E.H.; Park, H.; Ha, M.; Lee, K.Y.; Hong, Y.C.; Tamura, T.; Chang, N. Relationship between body-mass index and serum folate concentrations in pregnant women. Eur. J. Clin. Nutr. 2012, 66, 136-138. [CrossRef] [PubMed]

7. Serum and Red Blood Cell Folate Concentrations for Assessing Folate Status in Populations. Available online: http:/ /apps.who.int/iris/bitstream/10665/75584/1/WHO_NMH_NHD_EPG_12.1_eng.pdf (accessed on 1 October 2016).

8. Wald, N.J.; Morris, J.K.; Blakemore, C. Public health failure in the prevention of neural tube defects: Time to abandon the tolerable upper intake level of folate. Pub. Health Rev. 2018, 39, 2. [CrossRef] [PubMed]

9. Guelinckx, I.; Devlieger, R.; Beckers, K.; Vansant, G. Maternal obesity: Pregnancy complications, gestational weight gain and nutrition. Obes. Rev. 2008, 9, 140-150. [CrossRef] [PubMed]

10. Moran, L.J.; Sui, Z.; Cramp, C.S.; Dodd, J.M. A decrease in diet quality occurs during pregnancy in overweight and obese women which is maintained post-partum. Int. J. Obes. 2012, 37, 704-711. [CrossRef] [PubMed]

11. Rifas-Shiman, S.L.; Rich-Edwards, J.W.; Kleinman, K.P.; Oken, E.; Gillman, M.W. Dietary Quality during Pregnancy Varies by Maternal Characteristics in Project Viva: A US Cohort. J. Am. Diet. Assoc. 2009, 109, 1004-1011. [CrossRef] [PubMed]

12. Mojtabai, R. Body mass index and serum folate in childbearing age women. Eur. J. Epidemiol. 2004, 19, 1029-1036. [CrossRef] [PubMed]

13. Da Silva, V.R.; Hausman, D.B.; Kauwell, G.P.; Sokolow, A.; Tackett, R.L.; Rathbun, S.L.; Bailey, L.B. Obesity affects short-term folate pharmacokinetics in women of childbearing age. Int. J. Obes. 2013, 37, 1608-1610. [CrossRef] [PubMed]

14. Ray, J.G.; Wyatt, P.R.; Vermeulen, M.J.; Meier, C.; Cole, D.E. Greater maternal weight and the ongoing risk of neural tube defects after folic acid flour fortification. Obstet. Gynecol. 2005, 105, 261-265. [CrossRef] [PubMed]

15. Eichholzer, M.; Tonz, O.; Zimmermann, R. Folic acid: A public-health challenge. Lancet 2006, 367, $1352-1361$. [CrossRef]

16. Oyama, K.; Sugimura, Y.; Murase, T.; Uchida, A.; Hayasaka, S.; Oiso, Y.; Murata, Y. Folic acid prevents congenital malformations in the offspring of diabetic mice. Endocr. J. 2009, 56, 29-37. [CrossRef] [PubMed]

17. Pickell, L.; Li, D.Q.; Brown, K.; Mikael, L.G.; Wang, X.L.; Wu, Q.; Luo, L.; Jerome-Majewska, L.; Rozen, R. Methylenetetrahydrofolate Reductase Deficiency and Low Dietary Folate Increase Embryonic Delay and Placental Abnormalities in Mice. Birth Defects Res. A Clin. Mol. Teratol. 2009, 85, 531-541. [CrossRef] [PubMed]

18. Antony, A.C. In utero physiology: Role of folic acid in nutrient delivery and fetal development. Am. J. Clin. Nutr. 2007, 85, 598S-603S. [CrossRef] [PubMed]

19. Solanky, N.; Jimenez, A.R.; D'Souza, S.W.; Sibley, C.P.; Glazier, J.D. Expression of folate transporters in human placenta and implications for homocysteine metabolism. Placenta 2010, 31, 134-143. [CrossRef] [PubMed]

20. Castano, E.; Caviedes, L.; Hirsch, S.; Llanos, M.; Iniguez, G.; Ronco, A.M. Folate Transporters in Placentas from Preterm Newborns and Their Relation to Cord Blood Folate and Vitamin B12 Levels. PLoS ONE 2017, 12, e0170389. [CrossRef] [PubMed]

21. Solanky, N.; Jimenez, A.R.; D'Souza, S.W.; Sibley, C.P.; Glazier, J.D. Folate Transporters in First Trimester and Term Human Placenta. Reprod. Sci. 2009, 16, 81a-82a.

22. Carter, M.F.; Powell, T.L.; Li, C.; Myatt, L.; Dudley, D.; Nathanielsz, P.; Jansson, T. Fetal serum folate concentrations and placental folate transport in obese women. Am. J. Obstet. Gynecol. 2011. [CrossRef] [PubMed]

23. Martino, J.; Sebert, S.; Segura, M.T.; Garcia-Valdes, L.; Florido, J.; Padilla, M.C.; Marcos, A.; Rueda, R.; McArdle, H.J.; Budge, H.; et al. Maternal body weight and gestational diabetes differentially influence placental and pregnancy outcomes. J. Clin. Endocrinol. Metab. 2016, 101, 59-68. [CrossRef] [PubMed] 
24. Torres-Espinola, F.J.; Berglund, S.K.; Garcia-Valdes, L.M.; Segura, M.T.; Jerez, A.; Campos, D.; Moreno-Torres, R.; Rueda, R.; Catena, A.; Perez-Garcia, M.; et al. Maternal obesity, overweight and gestational diabetes affect the offspring neurodevelopment at 6 and 18 months of age-A follow up from the PREOBE cohort. PLoS ONE 2015, 10, e0133010. [CrossRef] [PubMed]

25. Garcia-Valdes, L.; Campoy, C.; Hayes, H.; Florido, J.; Rusanova, I.; Miranda, M.T.; McArdle, H.J. The impact of maternal obesity on iron status, placental transferrin receptor expression and hepcidin expression in human pregnancy. Int. J. Obes. 2015, 39, 571-578. [CrossRef] [PubMed]

26. Berglund, S.K.; Garcia-Valdes, L.; Torres-Espinola, F.J.; Segura, M.T.; Martinez-Zaldivar, C.; Aguilar, M.J.; Agil, A.; Lorente, J.A.; Florido, J.; Padilla, C.; et al. Maternal, fetal and perinatal alterations associated with obesity, overweight and gestational diabetes: An observational cohort study (PREOBE). BMC Public Health 2016, 16, 207. [CrossRef] [PubMed]

27. Documento, C.d. Asistencia a la gestante con diabetes. Guía de práctica clínica actualizada en 2014 Grupo Español de Diabetes y Embarazo (GEDE). Av. Diabetol. 2015, 31, 45-59.

28. Rasmussen, K.M.; Yaktine, A.L. Weight gain during pregnancy: Reexamining the guidelines; The National Academies Press: Washington, DC, USA, 2009.

29. Casas-Agustench, P.; Lopez-Uriarte, P.; Bullo, M.; Ros, E.; Gomez-Flores, A.; Salas-Salvado, J. Acute effects of three high-fat meals with different fat saturations on energy expenditure, substrate oxidation and satiety. Clin. Nutr. 2009, 28, 39-45. [CrossRef] [PubMed]

30. Livak, K.J.; Schmittgen, T.D. Analysis of relative gene expression data using real-time quantitative PCR and the 2(T)(-Delta Delta C) method. Methods 2001, 25, 402-408. [CrossRef] [PubMed]

31. Caviedes, L.; Iñiguez, G.; Hidalgo, P.; Castro, J.J.; Castaño, E.; Llanos, M.; Hirsch, S.; Ronco, A.M. Relationship between folate transporters expression in human placentas at term and birth weights. Placenta 2016, 38, 24-28. [CrossRef] [PubMed]

32. Astbury, S.; Mostyn, A.; Symonds, M.E.; Bell, R.C. Nutrient availability, the microbiome, and intestinal transport during pregnancy. Appl. Physiol. Nutr. Metab. 2015, 40, 1100-1106. [CrossRef] [PubMed]

33. Astbury, S.; Song, A.; Zhou, M.; Nielsen, B.; Hoedl, A.; Willing, B.P.; Symonds, M.E.; Bell, R.C. High fructose intake during pregnancy in rats influences the maternal microbiome and gut development in the offspring. Front. Genet. 2018, 9, 203. [CrossRef] [PubMed]

34. Khong, T.Y.; Hague, W.M. The placenta in maternal hyperhomocysteinaemia. Br. J. Obstet. Gynaecol. 1999, 106, 273-278. [CrossRef] [PubMed]

35. Bergen, N.E.; Timmermans, S.; Hofman, A.; Steegers-Theunissen, R.P.; Russcher, H.; Lindemans, J.; Jaddoe, V.W.; Steegers, E.A. First trimester homocysteine and folate levels are associated with increased adverse pregnancy outcomes. Reprod. Sci. 2011, 18, S22. [CrossRef]

36. Friso, S.; Choi, S.W.; Girelli, D.; Mason, J.B.; Dolnikowski, G.G.; Bagley, P.J.; Olivieri, O.; Jacques, P.F.; Rosenberg, I.H.; Corrocher, R.; et al. A common mutation in the 5,10-methylenetetrahydrofolate reductase gene affects genomic DNA methylation through an interaction with folate status. Proc. Natl. Acad. Sci. USA 2002, 99, 5606-5611. [CrossRef] [PubMed]

37. Di Simone, N.; Maggiano, N.; Caliandro, D.; Riccardi, P.; Evangelista, A.; Carducci, B.; Caruso, A. Homocysteine induces trophoblast cell death with apoptotic features. Biol. Reprod. 2003, 69, 1129-1134. [CrossRef] [PubMed]

38. Ulrey, C.L.; Liu, L.; Andrews, L.G.; Tollefsbol, T.O. The impact of metabolism on DNA methylation. Hum. Mol. Genet. 2005, 14, R139-R147. [CrossRef] [PubMed]

39. Mikael, L.G.; Pancer, J.; Jiang, X.; Wu, Q.; Caudill, M.; Rozen, R. Low dietary folate and methylenetetrahydrofolate reductase deficiency may lead to pregnancy complications through modulation of ApoAI and IFN-gamma in spleen and placenta, and through reduction of methylation potential. Mol. Nutr. Food Res. 2012. [CrossRef]

40. Cooper, W.N.; Khulan, B.; Owens, S.; Elks, C.E.; Seidel, V.; Prentice, A.M.; Belteki, G.; Ong, K.K.; Affara, N.A.; Constancia, M.; et al. DNA methylation profiling at imprinted loci after periconceptional micronutrient supplementation in humans: Results of a pilot randomized controlled trial. FASEB J. 2012, 26, 1782-1790. [CrossRef] [PubMed]

41. Rampersaud, G.C.; Kauwell, G.P.A.; Hutson, A.D.; Cerda, J.J.; Bailey, L.B. Genomic DNA methylation decreases in response to moderate folate depletion in elderly women. Am. J. Clin. Nutr. 2000, 72, 998-1003. [CrossRef] [PubMed] 
42. Seki, Y.; Williams, L.; Vuguin, P.M.; Charron, M.J. Minireview: Epigenetic programming of diabetes and obesity: Animal models. Endocrinology 2012, 153, 1031-1038. [CrossRef] [PubMed]

43. Radaelli, T.; Lepercq, J.; Varastehpour, A.; Basu, S.; Catalano, P.M.; Hauguel-De Mouzon, S. Differential regulation of genes for fetoplacental lipid pathways in pregnancy with gestational and type 1 diabetes mellitus. Am. J. Obstet. Gynecol. 2009. [CrossRef] [PubMed]

44. Maccani, M.A.; Marsit, C.J. Epigenetics in the Placenta. Am. J. Reprod. Immunol. 2009, 62, 78-89. [CrossRef] [PubMed]

45. Niculescu, M.D.; Zeisel, S.H. Diet, methyl donors and DNA methylation: Interactions between dietary folate, methionine and choline. J. Nutr. 2002, 132, 2333S-2335S. [CrossRef] [PubMed]

46. Robertson, K.D.; Ait-Si-Ali, S.; Yokochi, T.; Wade, P.A.; Jones, P.L.; Wolffe, A.P. DNMT1 forms a complex with Rb, E2F1 and HDAC1 and represses transcription from E2F-responsive promoters. Nat. Genet. 2000, 25, 338-342. [CrossRef] [PubMed]

47. Martino, J. Metabolic Alterations Induced by High Maternal BMI and Gestational Diabetes in Maternal, Placental and Neonatal Outcomes. Ph.D. Thesis, The University of Nottingham, Nottingham, UK, 2013.

48. Symonds, M.E.; Bloor, I.; Ojha, S.; Budge, H. The placenta, maternal diet and adipose tissue development in the newborn. Ann. Nutr. Metab. 2017, 70, 232-235. [CrossRef] [PubMed]

(C) 2018 by the authors. Licensee MDPI, Basel, Switzerland. This article is an open access article distributed under the terms and conditions of the Creative Commons Attribution (CC BY) license (http://creativecommons.org/licenses/by/4.0/). 